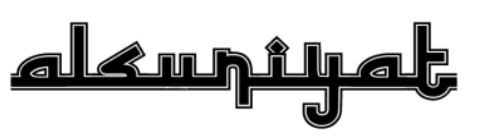

JURNAL PENELITIAN BAHASA, SASTRA, DAN

BUDAYA ARAB

P-ISSN: 2615-7241 | E-ISSN: 2721-480X // Vol. 3 No. 2 | 88-100

๑) ht.tps://ejournal.upi.edu/index.php/alsuniyat/index

\title{
Pembelajaran Daring Melalui Teknik Kolaboratif pada Keterampilan Menulis Peserta Didik di SMA Darul Quran Kota Mojokerto
}

\author{
Maftuhatul Umamah, Muassomah \\ Universitas Islam Negeri Maulana Malik Ibrahim Malang, Indonesia \\ Email: maftuhatulumamah1979@gmail.com
}

\begin{abstract}
:
This study explores online learning implementation using collaborative techniques on writing skill students at Darul Quran Senior High School, Mojokerto. This study uses descriptive qualitative methods with three data collection techniques: observation, interviews, and documentation. This study's results reveal several steps used by the teacher, namely: first, the teacher explains the basic competencies, materials, indicators, and learning objectives. Second, the teacher uploads the video into the Google classroom, and the students focus on recording the things contained in the video. Third, students are divided into several groups to discuss what was shown in the video and create it according to their creativity. Fourth, students conclude the learning material studied and provide responses and appreciation to students who have shown an increased attitude of cooperation and discipline during the learning process. Finally, collaborative techniques can invite students to be active, build cooperation, and feel confident in completing writing skill material tasks.
\end{abstract}

Keywords:

Collaborative Learning; Collaborative Techniques; Writing Skill

\begin{abstract}
Abstrak:
Penelitian ini mengeksplorasikan pelaksanaan pembelajaran secara daring dengan menggunakan teknik kolaboratif pada mahārah kitābah peserta didik di SMA Darul Quran, Mojokerto. Penelitian ini menggunakan metode kualitatif deskriptif dengan tiga teknik pengumpulan data yakni: observasi, wawancara dan dokumentasi. Hasil dari penelitian ini mengungkapkan beberapa langkah yang digunakan oleh guru yakni: pertama, guru menjelaskan kompetensi dasar, materi, indikator, dan tujuan pembelajaran. kedua, guru mengunggah video ke dalam Google classroom dan peserta didik fokus mencatat hal-hal yang terdapat dalam video tersebut. ketiga, Peserta didik dibagi dalam beberapa kelompok untuk berdiskusi tentang apa yang ditampilkan dalam video dan mengkreasikannya sesuai kreatifitas mereka. keempat, Peserta didik menyimpulkan materi pembelajaran yang telah dipelajari, memberikan tanggapan serta apresiasi kepada peserta didik yang telah menunjukkan peningkatan sikap kerjasama dan disiplin selama proses pembelajaran. akhirnya, penggunaan teknik kolaboratif mampu mengajak peserta didik untuk aktif, membangun kerja sama, serta rasa percaya diri dalam menyelesaikan tugas-tugas materi mahārah kitābah.

Kata Kunci:

Mahārah Kitābah; Pembelajaran Daring; Teknik Kolaboratif
\end{abstract}

\section{PENDAHULUAN}

Menyikapi perkembangan zaman di era digital 4.0, Indonesia menyadari pentingnya menyiapkan generasi muda yang kreatif, terampil, dan proaktif (Mubarak dkk., 2020). Hal ini senada dengan tujuan pembelajaran pada kurikulum 2013 (K-13) yaitu mempersiapkan manusia Indonesia agar memiliki kemampuan hidup sebagai pribadi dan warga negara yang beriman, produktif, kreatif, inovatif, dan afektif, serta mampu berkontribusi pada kehidupan bermasyarakat, berbangsa, bernegara, dan peradaban dunia, serta mampu bekerja secara efsien baik individu maupun berkelompok (Albantani, 2015). 
ALSUNIYAT: Jurnal Penelitian Bahasa, Sastra, dan Budaya Arab

Pembelajaran kolaboratif merupakan suatu landasan untuk membangun keterampilan bekerjasama, baik oleh guru maupun peserta didik. Bernie Trilling dan carles Fadel (2009) menyatakan bahwa pentingnya menyeimbangkan implementasi pembelajaran berbasis guru dan berbasis peserta didik merupakan suatu langkah pembelajaran yang bijak (Trilling \& Fadel, 2009). Davis (2013) mengatakan bahwa pembelajaran kolaboratif berlangsung apabila pelajar dan pengajar bekerjasama menciptakan pengetahuan. Pembelajaran kolaboratif adalah sebuah pedagogi yang pusatnya terletak dalam asumsi bahwa manusia selalu menciptakan makna bersama dan proses tersebut selalu memperkaya dan memperluas wawasan mereka.

Pembelajaran kolaboratif cenderung memiliki ketergantungan dengan pihak lain. Biemiller (1993) menyatakan bahwa pengaturan pembelajaran mendorong para peserta didik memberikan bantuan kepada yang lain dan pihak lain menerimanya. Hal ini memungkinkan adanya saling ketergantungan (Nugrawiyati, 2017). Andaikan kondisi ini tidak terjadi, yaitu tidak adanya saling ketergantungan maka kerja kelompok tidak akan terwujud dan hasilnya tidak mencapai produktif. Bentuk pembelajaran kelompok kecil lebih sulit daripada mengajar kepada kelompok besar atau kelas karena kita akan banyak menghadapi berbagai persoalan manajemen (Donald dkk., 2006).

Munculnya wabah covid-19 dan kebijakan pemerintah diberlakukannya social distancing nampaknya berpengaruh terhadap proses pembelajaran yaitu dengan melalui media daring atau online (Julaeha, 2011). Pengajar dan pelajar tidak lagi bertatap muka secara langsung di dalam kelas, melainkan tatap muka melalui media online, misalnya menggunakan aplikasi zoom (Video Conferencing, Web Conferencing, Webinars, Screen Sharing, t.t.), atau beberapa multimedia interaktif seperti Cartoon Story Maker, Arabic Online, Camtasia, Active Presenter, dan lain sebagainya (Ilmiani, Ahmadi, Rahman, \& Rahmah, 2020). Sebagaimana disampaikan Hari Srinivas tentang manfaat pembelajaran kolaboratif ini sehubungan dengan implementasi pendidikan karakter yang sedang dikembangkan di sekolah-sekolah Indonesia oleh Kementerian Pendidikan dan Kebudayaan seperti, terbuka, tenggang rasa, menghargai pendapat orang lain, berani berpendapat kritis, logis dan dinamis (Srinivas, 2011).

Keterampilan menulis (mahārah kitābah) merupakan salah satu keterampilan yang produktif dan dianggap sulit dalam pembelajaran bahasa Arab, sehingga tenaga pendidik membutuhkan waktu yang lama untuk mengajarkan keterampilan tersebut (Rosyidah \& Basid, 2017). Maka dari itu dibutuhkan pendekatan, metode ataupun strategi yang sesuai dan mudah untuk diterapkan (Makrufah, 2019). Pemanfaatan teknologi informasi pun menjadi suatu hal 
yang sangat direkomendasikan dari para peneliti dalam pembelajaran bahasa Arab (Haniah, 2014), seperti penggunaan media sosial yang umum digunakan oleh masyarakat yakni whatsapp (Sa`diyah, 2019), facebook (Linur \& Mubarak, 2020), dan Instagram (Audina \& Muassomah, 2020). Memperbanyak latihan menulis dengan konsisten dapat meningkatkan keterampilan menulis peserta didik dan juga peserta didik harus memperhatikan beberapa aspek dalam menulis yaitu, penguasaan mufradāt (kosa kata), qawā`id (tata bahasa) balāghah (sastra) dan pilihan diksi yang tepat (Khomsah \& Imron, 2020).

Penelitian ini bertujuan untuk mengamati proses pembelajaran daring dengan menggunakan teknik kolaboratif pada pada keterampilan mahārah kitābah yang berlandaskan pada teori konstuktivisme social dari Lev Vygotsky (ZPD). Hal ini diharapkan dapat meningkatkan kerjasama antar peserta didik dalam meningkatkan keterampilan menulis bahasa Arab (mahārah kitābah) peserta didik. Berdasarkan hal tersebut, penelitian ini merumuskan tiga pertanyaan: (1) Bagaimana proses pembelajaran daring bahasa Arab (2) Bagaimana implementasi pembelajaran daring bahasa Arab dengan menggunakan teknik kolaboratif (3) Bagaimana implikasi dari pembelajaran daring bahasa Arab melalui teknik kolaboratif dan bentuk - bentuk hasil pembelajarannya?

Penelitian ini memiliki tiga asumsi yang mendasar yaitu: pertama, pembelajaran daring bahasa Arab dibutuhkan kolaboratif antar guru dan peserta didik, sehingga dapat memudahkan peserta didik dalam menyelesaikan tugas yang diberikan. Kedua, materi yang diberikan berisi pembiasaan mengembangkan keterampilan menulis secara kritis dan tepat. Misalnya membuat peta konsep, skema, bagan atau peta pikiran dengan kreativitas peserta didik. Ketiga, pembelajaran kolaboratif dapat mempermudah guru dan peserta didik dalam menyampaikan ataupun menerima materi.

\section{METODE}

Penelitian ini didasarkan pada pendekatan deskriptif kualitatif. Penelitian ini akan mendiskripsikan penerapan metode kolaboratif pada pembelajaran mahārah kitābah kelas X di SMA Darul Quran kota Mojokerto. Proses penelitian dilakukan dengan hadir secara langsung di lapangan untuk melakukan pengamatan yang bersifat deskriptif analitis, kemudian mengumpulkan dan membuat laporan data hasil dari penelitian tersebut. Berdasarkan hasil temuan data yang telah dianalisis, diharapkan penelitian ini dapat bermanfaat bagi 
pembelajaran bahasa Arab di lembaga sekolah SMA Darul Quran kota Mojokerto maupun lembaga lainnya.

Data dan informasi penelitian ini dikumpulkan melalui beberapa teknik yaitu: observasi, wawancara, angket, dan dokumentasi. Dalam penelitian ini, observasi dilakukan melalui pengamatan langsung secara terus menerus pada saat proses pembelajaran bahasa Arab berlangsung. Peneliti mengunjungi lokasi Whatsapp Group (WAG) atau Google Classroom (GC) dan ikut serta dalam pembelajaran mahārah kitābah untuk mengamati proses pembelajaran dan permasalahan yang dihadapi oleh peserta didik sehingga peneliti dapat menemukan solusi yaitu dengan menerapkan metode kolaboratif. Adapun wawancara yang dilakukan oleh peneliti bertujuan untuk mendapatkan informasi dari dua guru. Kemudian pemberian angket kepada 25 peserta didik dan mendokumentasikan informasi yang ditemukan. Instrumen tersebut dibutuhkan untuk menggali informasi dan data yang berupa dokumen tertulis tentang sekolah SMA Darul Quran di antaranya berupa buku panduan kurikulum, silabus, panduan pembelajaran daring kolaboratif, dan dokumen gambar berupa hasil pembelajaran karya peserta didik. sumber data yang diambil pada penelitian ini adalah 25 peserta didik kelas X SMA Darul Quran kota Mojokerto.

Peneliti melakukan analisis deskriptif berdasarkan hasil penelitian yang dilakukan melalui observasi dan wawancara. Analisis deskriptif dilakukan dengan mendeskripsikan hasil penelitian penerapan metode kolaboratif dalam proses belajar mengajar. Data lapangan hasil observasi dan wawancara dipelihara keasliannya sesuai dengan informasi dari informan. Analisis deskriptif dilakukan dengan tiga langkah yaitu, reduction, display, dan conclucion drawing/verifying. Penyajian data dalam penelitian ini berbentuk uraian singkat, yaitu merangkum dan memilih hal-hal yang pokok. Selanjutnya mendisplay data dalam bentuk tabel, bagan, atau skema yang berpola terorganisasi, kemudian langkah terakhir ialah penarikan kesimpulan dan verifikasi.

\section{HASIL DAN PEMBAHASAN}

Proses pembelajaran Daring bahasa Arab Teknik Kolaboratif di SMA Darul Quran Kota Mojokerto.

Permulaan Maret 2020 Indonesia memberlakukan social distancing, atau lebih dikenal dengan physical distancing (menjaga jarak fisik). Hal ini diupayakan untuk memutus rantai penyebaran corona virus dissease atau sering disingkat covid-19 di tengah masyarakat. 
Menanggapi hal tersebut, Kementerian Pendidikan dan Kebudayaan (Kemdikbud) memberlakukan kebijakan belajar dari rumah, melalui pembelajaran daring atau media online (Media, t.t.).

SMA Darul Quran Kota Mojokerto merupakan salah satu lembaga pendidikan yang diliburkan dan melanjutkan proses pembelajaran melalui media daring. Pembelajaran berlangsung antara guru dan peserta didik dengan media yang telah disepakati, kemudian guru pengampu materi akan melangsungkan tatap muka sesuai dengan jadwal yang telah ditetapkan. Dalam prosesnya, guru melakukan metode pembelajaran kolaboratif antara bahasa Arab dengan bahasa Indonesia. Keduanya memiliki empat mahārah yang sama, yaitu mahārah istima', mahārah kalām, mahārah qira'ah, dan mahārah kitābah. Adapun dalam penelitian ini, peneliti memilih fokus kepada pembelajaran mahārah kitābah atau keterampilan menulis.

Pembelajaran mahārah kitābah di SMA Darul Quran merupakan keterampilan berbahasa yang memiliki tingkat kesulitan yang tinggi dibandingkan tiga kemampuan berbahasa yang lain. Kemampuan menulis menghendaki penguasaan berbagai unsur kebahasaan baik unsur dalam (instrinsik) maupun unsur luar (ekstrinsik) yang membentuk susunan tulisan. Proses pembelajaran berlangsung menggunakan metode imla' manqul dan imla' manẓur. Hal ini ditujukan untuk memperbaiki kemampuan peserta didik dalam menulis huruf dan kata dalam bahasa Arab. Adapun tekniknya yaitu, pertama; peserta didik membaca teks berbahasa Arab, kemudian peserta didik menulis ulang tanpa melihat tulisan tersebut. Kedua; peserta didik diminta untuk menulis sebagian kalimat yang sudah dipelajari dan diperbolehkan melihat teks sekiranya dibutuhkan (Mustofa, 2011).

Pembelajaran kolaboratif daring dilakukan selama dua jam dalam satu minggu, mulai pukul 07.30-08.30 WIB pada hari Senin dan Kamis. Peserta didik diminta untuk online saat jam pelajaran dimulai. Pembelajaran dimulai dengan intruksi dari guru melalui grup WhatsApp, kemudian peserta didik diminta untuk bergabung di classroom untuk menerima materi dari guru. Selanjutnya guru memberikan penugasan berserta deskripsinya. Setiap peserta didik harus mengumpulkan tugas sebelum pukul 21.00 WIB. Apabila tidak mengumpulkan, maka peserta didik dianggap tidak hadir. Dan jika peserta didik mengalami kesulitan dan pertanyaan, peserta didik mengkonfirmasinya kepada guru melalui WhatsApp pribadi.

\section{Implementasi pembelajaran daring bahasa Arab dengan menggunakan teknik kolaboratif}


Penerapan pembelajaran daring mahārah kitābah menuntut guru menggunakan strategi dan metode yang tepat untuk mencapai tujuan pembelajaran yang diinginkan. Namun, hal tersebut belum efektif, dikarenakan peserta didik masih mengalami kesulitan ketika menuntaskan tugas yang diberikan oleh guru. Oleh karena itu, dalam penelitian ini peneliti menjadikan pembelajaran kolaboratif media daring sebagai inovasi pembelajaran.

Salah satu inovasi yang dilakukan ialah, guru memberikan tugas Ta'bir Hur (menulis bebas). Peserta didik diminta untuk memilih tema yang sudah ditentukan, kemudian peserta didik menulis berdasarkan tema tersebut dengan menggunakan tarkib, kosa kata dan kemampuan berbahasa yang telah dipelajari. Hal ini diharapkan dapat melatih peserta didik untuk memperoleh ide-ide kritis kemudian menuangkannya dalam bentuk tulisan dengan cara yang sistematis, dan mudah dipahami (Mustofa, 2011). Selain itu, peserta didik diminta untuk mencantumkan bahasa Indonesia-nya di samping tulisan berbahasa Arab. Hal ini bertujuan agar peserta didik mengembangkan keterampilan berfikir tinggi, meningkatkan daya ingat peserta didik, dan meningkatkan sikap positif pada materi pembelajaran (Warsono, 2013).

\section{Gambar 1. Implementasi tahapan -tahapan pembelajaran daring bahasa Arab}

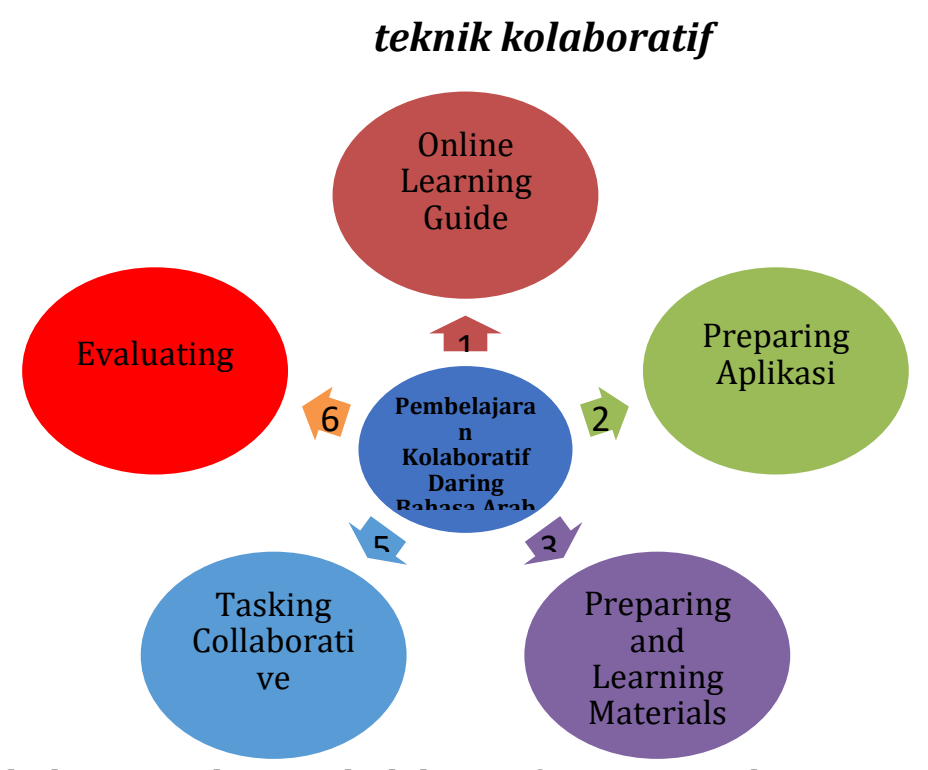

Penerapan pembelajaran daring kolaboratif ini memakai sistem kelas agar lebih maksimal dalam mengaplikasikannya, yaitu pada kelas X IPS. Berikut adalah petunjuk atau sintak pembelajarannya berdasarkan bagan di dalam gambar 1 :

1. Pengajar membuat panduan pembelajaran daring kolaboratif mahārah kitābah.

2. Pengajar menyiapkan aplikasi WAG , Classroom yang terdiri dari guru dan peserta didik.

3. Pengajar menyiapkan materi pembelajaran beserta administrasinya mulai dari aplikasi, absen online, link pengumpulan tugas, dan daftar penilaiannya. 
4. Proses pembelajaran menggunakan tema atau materi tentang pembelajaran bermakna beserta implemantasinya sesuai anjuran dari pemerintah dan Dinas Pendidikan, dengan sementara mengesampingkan tujuan sesuai kurikulum Nasional dan Sekolah.

5. Proses penugasan dilakukan secara kolaboratif yaitu satu kesatuan materi kemudian dikembangkan dalam satu tugas, dan satu mahārah keterampilan yaitu mahārah kitābah. Adapun hasil akhirnya berupa peta konsep atau bentuk prosedur teks. Contoh tema yang diberikan ialah tentang wabah virus corona atau covid-19.

6. Pengajar menyiapkan evaluasi pembelajaran yang dirancang untuk mengetahui capaian kompetensi peserta didik pada proses pembelajaran berlangsung.

Gambar 2. Panduan pembelajaran daring bahasa Arab teknik kolaboratif

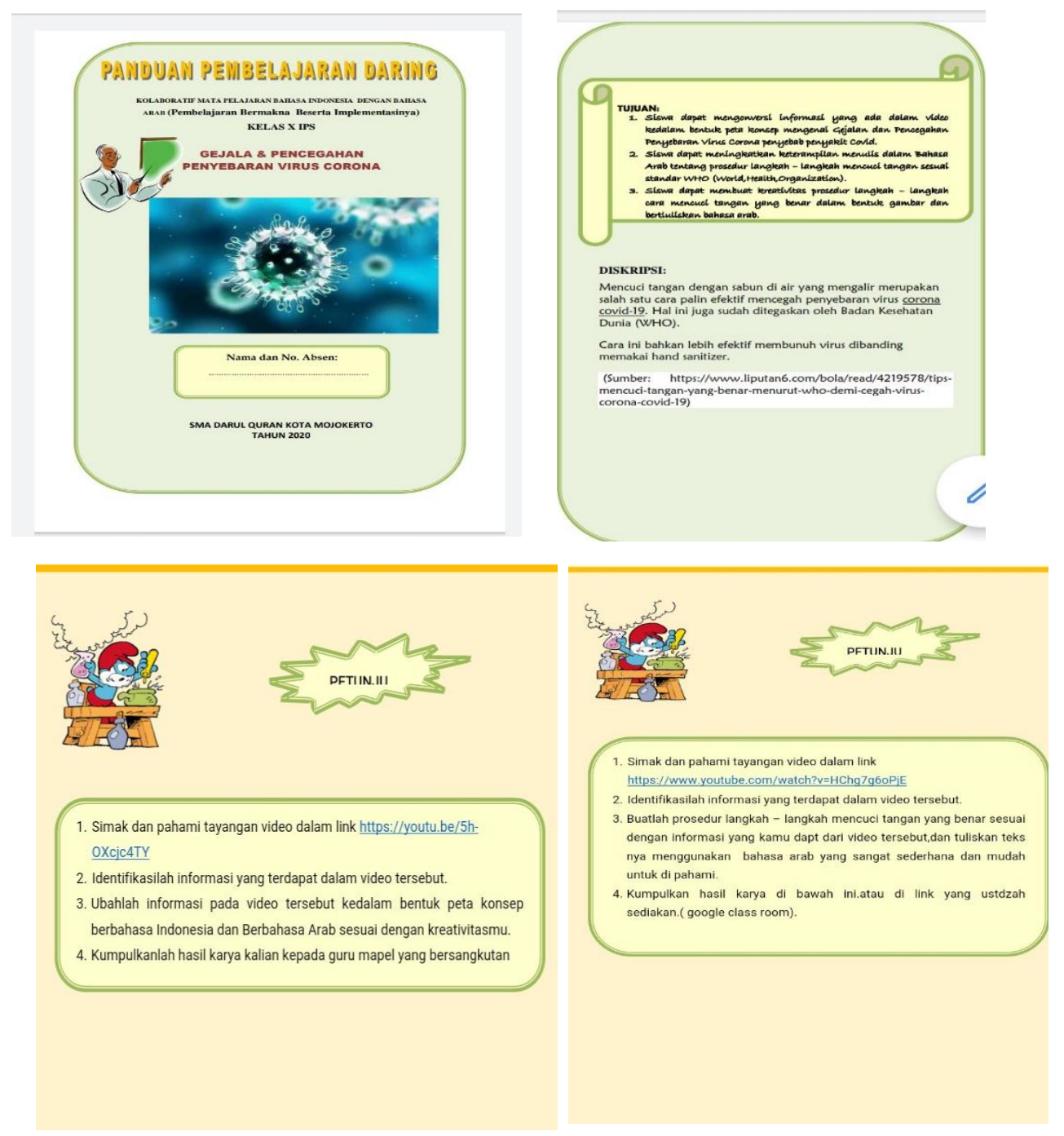

Vol. 3 No. 2 | 88-100

ALSUNIYAT, p-ISSN: 2615-7241, e-ISSN: 2721-480X 
ALSUNIYAT: Jurnal Penelitian Bahasa, Sastra, dan Budaya Arab

Gambar di atas merupakan contoh buku panduan pembelajaran daring dengan menggunakan teknik kolaboratif pada mahārah kitābah. Dua gambar di atas merupakan sampul dan deskripsi tujuan dari proses pembelajaran daring. Adapun dua gambar di bawahnya, merupakan ilustrasi penugasan yang diberikan oleh guru melalui media daring. Peserta didik diminta untuk menyimak dan memahami tayangan video yang terdapat di dalam link. Kemudian peserta didik melanjutkannya dengan mengerjakan tugas dari hasil video yang telah ditonton, yaitu membuat peta konsep berbahasa Indonesia disandingkan dengan bahasa Arab, dan membuat teks singkat berbahasa Arab berdasarkan informasi yang ditangkap dari video tersebut. Selanjutnya peserta didik diminta mengumpulkan tugas melalui jalur yang telah disepakati.

\section{Gambar 3. Tahapan evaluasi daring pembelajaran mahārah kitābah teknik kolaboratif}

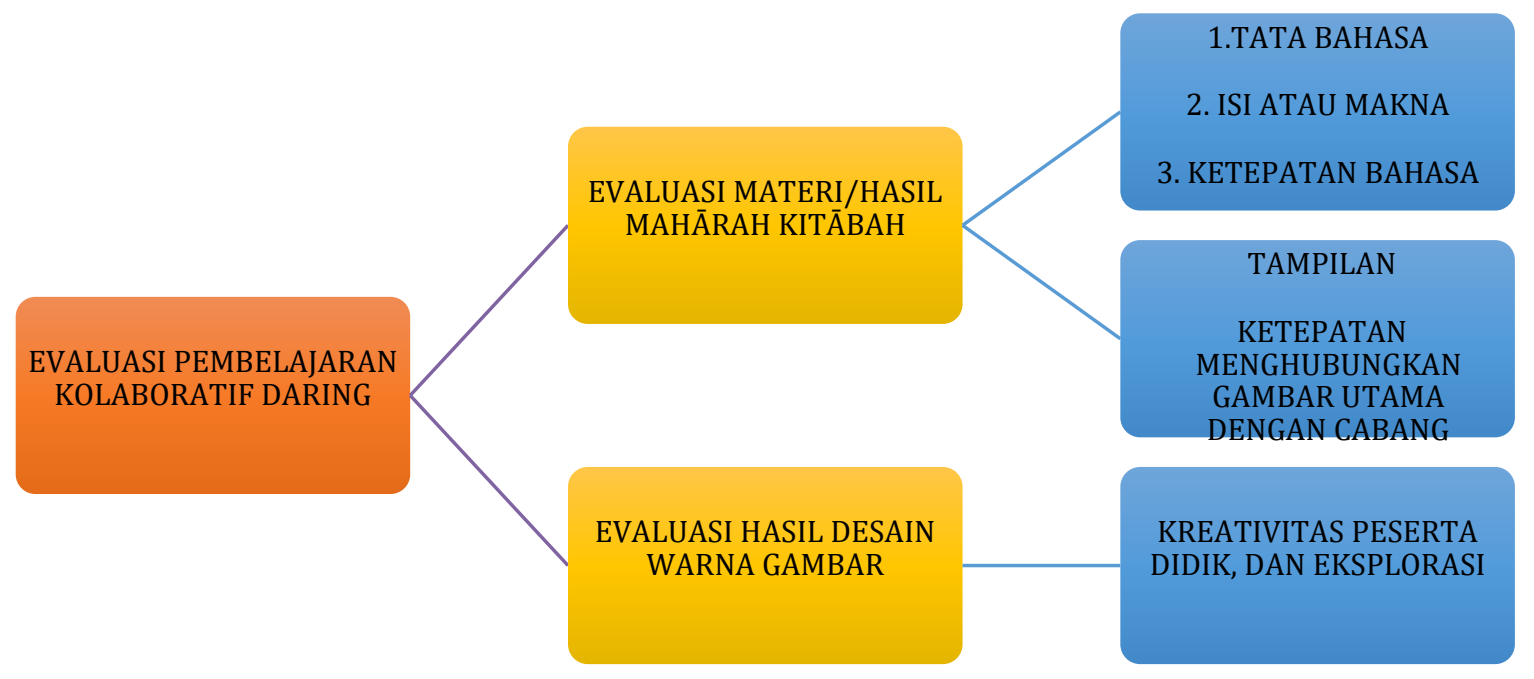

Evaluasi pembelajaran kolaboratif daring bahasa Arab antar mata pelajaran dilakukan dengan dua tahapan, yaitu : pertama, evaluasi materi/hasil mahārah kitābah. Tahapan evaluasi ini memiliki tiga komponen kebahasaan yang harus dipenuhi oleh peserta didik yaitu tata bahasa Arab yang sesuai kaidah, isi atau makna yang sesuai dengan tema yang diberikan, dan ketepatan bahasa atau kosa kata yang digunakan. Adapun komponen lainnya yaitu karya peserta didik di evaluasi berdasarkan nilai seni atau tampilan yang dihasilkan, serta ketepatan alur dalam menghubungkan gambar dengan cabang-cabangnya dalam pembuatan peta konsep. Kedua, evaluasi hasil desain dan warna gambar. Tahapan evaluasi ini melakukan penilaian 
terhadap tingkat kreatifitas peserta didik dan bagaimana peserta didik mampu mengeksplorasi idenya ke dalam karya yang dihasilkan.

\section{Implikasi dari pembelajaran daring bahasa Arab kolaboratif dengan bahasa Indonesia} dan bentuk - bentuk hasil pembelajarannya?

Dari beberapa gambar di atas, dapat disimpulkan bahwa pembelajaran kolaboratif daring bahasa Arab dalam mahārah kitābah terdiri dari :

(1) Membuat grup daring WAG. (2) Pengajar menyiapkan aplikasi bisa berupa classroom. (3) Pengajar menyiapkan panduan pembelajaran daring lengkap dengan administrasi pembelajarannya. (4) Pengajar menentukan topik atau tema pembelajaran lengkap dengan petunjuk pembelajarannya. (5) Pengajar menyiapkan tugas beserta petunjuknya dan kriteria penilaiannya. (6) Proses evaluasi dilakukan setelah pembelajaran selesai dengan tujuan agar peserta didik dapat mengetahui hasil pembelajarannya, mengetahui kekurangan dan kelebihan dari tugas yang telah dikerjakan, serta menjadi motivasi bagi peserta didik untuk meningkatkan semangat belajarnya dan memperbaikinya pada tugas berikutnya. Adapun tema - tema yang diberikan yaitu tentang pembelajaran bermakna dan implementasinya, serta kemandirian dan tanggung jawab selama masa sosial distance dalam menghadapi wabah virus corona.

Berikut hasil pembelajaran daring bahasa arab teknik kolaboratif dalam mahārah kitābah pada kelas X IPS.

Gambar 4. Membuat peta konsep mengenai gejala dan pencegahan penyebaran virus corona

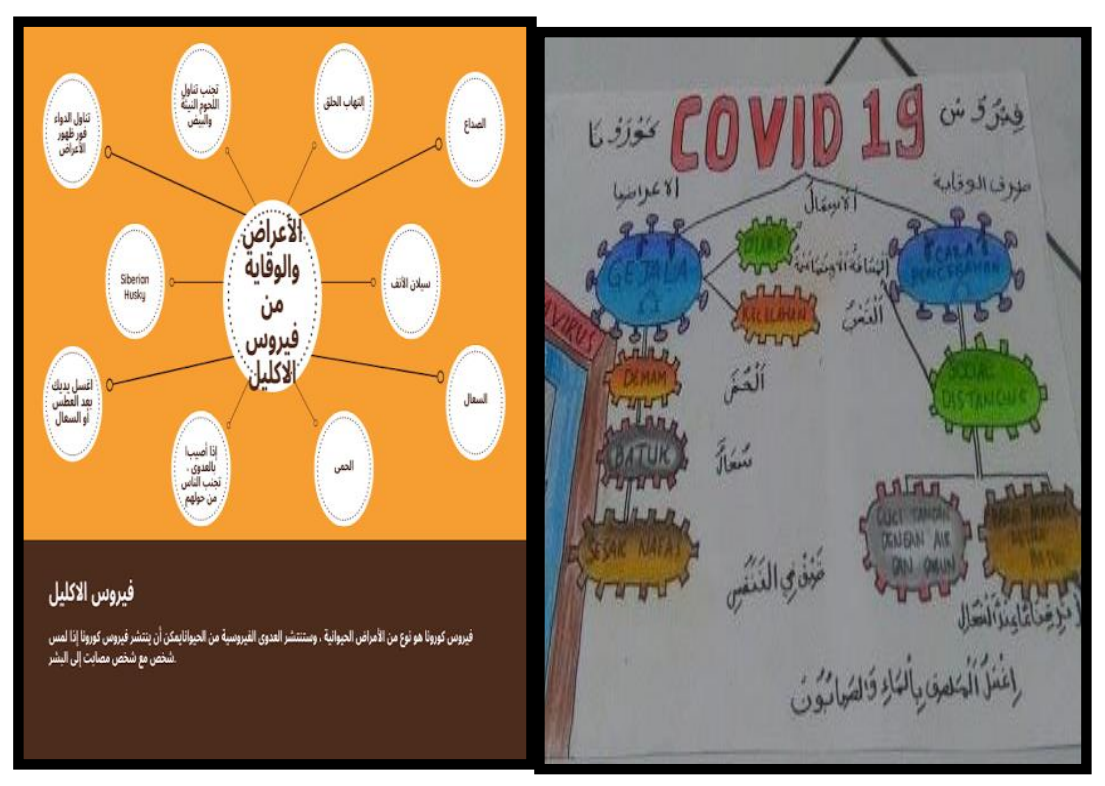

Vol. 3 No. 2 | 88-100

ALSUNIYAT, p-ISSN: 2615-7241, e-ISSN: 2721-480X 
Kedua gambar di atas merupakan peta konsep mengenai gejala dan pencegahan penyebaran virus corona. gambar pertama peserta didik berkreasi secara manual dengan alat menggambar. Adapun gambar kedua peserta didik berkreasi secara digital. Keduanya mencoba menyelesaikan tugas dengan sangat baik dan antusias. Hal ini dapat dilihat dari hasil karya mereka yang rapi dan memenuhi kreteria evaluasi yang kesesuaian isi dengan tema, penyesuain kosa kata dengan makna, dan penggunaan tata bahasa yang sesuai kaidah.

\section{Gambar 5 Prosedur langkah - langkah mencuci tangan menurut standar WHO}

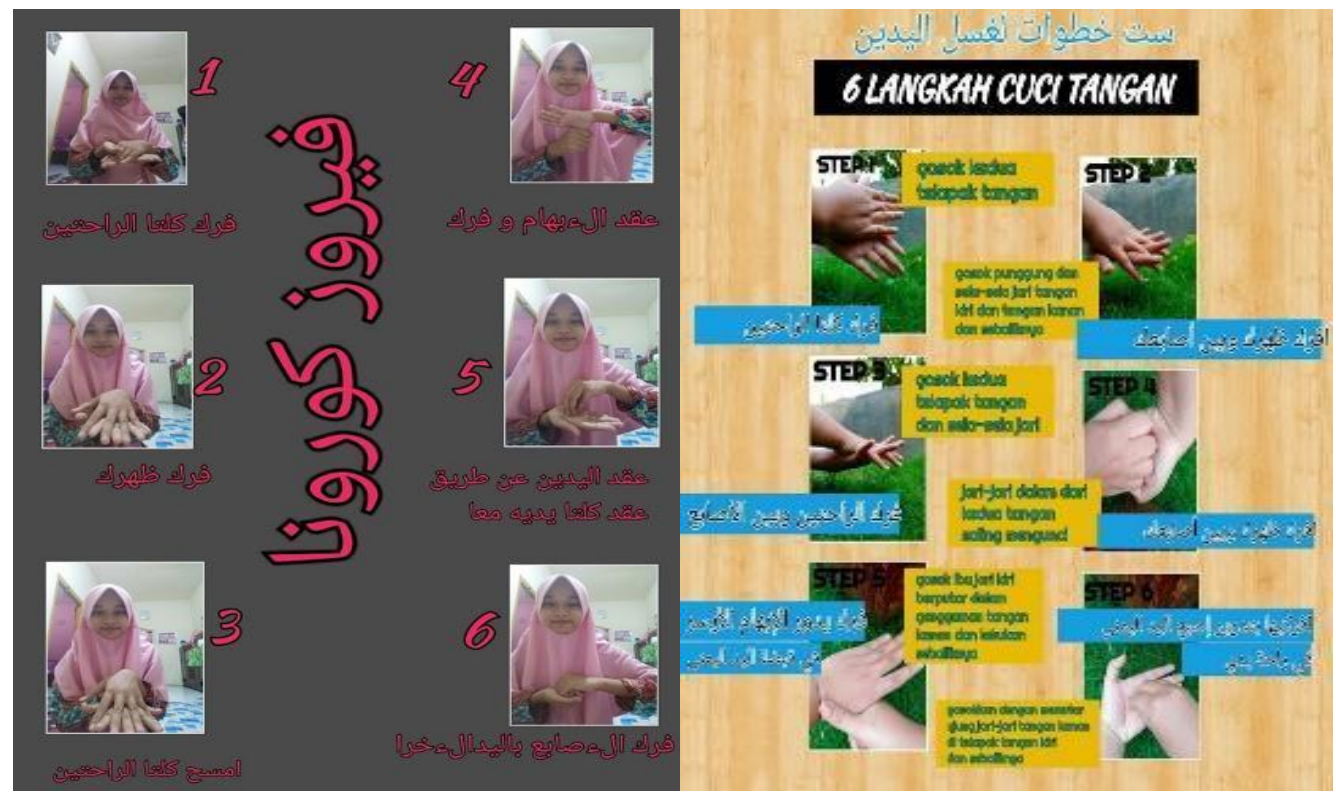

Adapun gambar di atas menunjukkan prosedur langkah-langkah mencuci tangan sesuai standar WHO ("World Health Organization," t.t.). Peserta didik menjelaskan langkah mencuci tangan melalui gambar yang dijelaskan dalam bahasa Arab dan bahasa Indonesia. Keduanya menyesuaikan isi dengan tema yang diberikan, penyesuaian kosa kata dengan makna dan gambar serta menggunakan tata bahasa yang sesuai dengan kaidah

Hasil observasi penelitian menunjukkan bahwa pembelajaran daring teknik kolaboratif bahasa Arab dapat meningkatkan keterampilan mahārah kitābah peserta didik. Peserta didik menjadi lebih semangat dan senang mengerjakan tugas. Efektifitas yang dimaksud ialah satu tugas bisa di kerjakan dalam satu materi dan proses pengumpulannya menjadi lebih efisien. Hal tersebut memberi pengaruh positif dalam meningkatkan hasil evaluasi pembelajaran peserta didik. Sebagaimana ditegaskan oleh Syaiful Mustofa bahwa aspek keterampilan yang paling inti adalah mengungkapkan pikiran dan tulisan.

Berikut ini ialah hasil responden sebanyak 25 peserta didik yang terdiri dari satu kelas X IPS yang melalui angket yang disebarkan via google form. 


\section{Gambar 6 : Diagram hasil angket google form tanggapan santri}

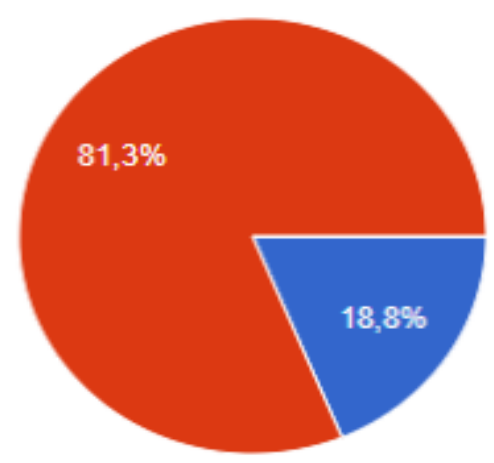

Diagram hasil angket google form yang berisi tanggapan peserta didik menunjukkan bahwa $81,3 \%$ peserta didik setuju dengan penggunaan pembelajaran kolaboratif dapat meningkatkan kemampuan menulis peserta didik. Adapun sekurang-kurangnya ada 18,8\% peserta didik yang merasa tidak maksimal ketika pembelajaran berlangsung dengan pembelajaran kolaboratif.

Dengan mengacu pada beberapa pertanyaan yang bersifat deskriptif, tentang seputar pembelajaran daring kolaboratif antara bahasa Arab dan bahasa Indonesia. Seluruh peserta didik memberikan tanggapan positif terhadap pembelajaran daring kolaboratif. Dengan demikian, peneliti menyimpulkan sebagai berikut: pertama, memudahkan guru dalam melatih keterampilan menulis peserta didik, tidak membosankan, dan mudah dimengerti; kedua, melatih peserta didik kritis dan berkompetisi dalam mengerjakan tugas dengan baik; ketiga, peserta didik dapat mengembangkan bahasanya sesuai dengan kemampuan bahasa arabnya; keempat, tugas tidak memberatkan peserta didik; kelima, peserta didik dapat mengaplikasikasikan materi dalam kehidupan sehari-hari. Meskipun pembelajaran kolaboratif tidak dapat diterapkan pada setiap mahārah bahasa Arab dengan memetakan beberapa materi dan KD yang sama, baik dalam pembelajaran bahasa Arab maupun bahasa Indonesia. Keenam, menjadikan peserta didik lebih kreatif dan inovatif dalam mengerjakan tugas.

\section{SIMPULAN}

Berdasarkan hasil temuan penelitian dan pembahasan di atas, bahwa pembelajaran kolaboratif daring bahasa Arab dengan bahasa Indonesia dapat diterapkan dalam berbagai media, tidak hanya pembelajaran melalui media daring, namun dapat juga diterapkan pada pembelajaran normal. Pembelajaran kolaboratif ini bisa dikembangkan pada semua mata 
ALSUNIYAT: Jurnal Penelitian Bahasa, Sastra, dan Budaya Arab

pelajaran serumpun bahasa, sains, agama maupun mata pelajaran umum. Kolaborasi dapat dilakukan dengan menyusun pedoman pembelajaran yang terperinci. Tujuan dan manfaat pembelajaran kolaboratif ialah dapat melatih kolaborasi antara guru dan peserta didik untuk memecahkan masalah bersama dalam sebuah kelompok, memupuk rasa kebersamaan antar peserta didik, serta setiap individu tidak dapat lepas dari kelompoknya. Mereka perlu mengenali sifat dan pendapat yang berbeda, serta mampu mengelolanya.

Penelitian ini memiliki keterbatasan, implementasi pembelajaran daring teknik kolaboratif, dan menyarankan agar pembelajaran kolaboratif ini dapat diterapkan pada mata pelajaran lain sehingga lebih banyak wadah dalam melatih kemampuan menulis dan berpikir peserta didik. Semakin banyak bahan yang harus ditulis, semakin banyak pula peluang untuk mengasah kemampuan peserta didik dalam menulis dan berpikir kritis.

\section{DAFTAR PUSTAKA}

Albantani, A. M. (2015). Implementasi kurikulum 2013 pada pembelajaran bahasa Arab di madrasah ibtidaiyah. Arabiyat: Jurnal Pendidikan Bahasa Arab dan Kebahasaaraban, 2(2), 178-191. https://doi.org/10.15408/a.v2i2.2127

Audina, N. A., \& Muassomah, M. (2020). Instagram: alternatif media dalam pengembangan mahārah al-kitābah. Al-ta'rib: Jurnal Ilmiah Program Studi Pendidikan Bahasa Arab IAIN Palangka Raya, 8(1), 77-90. https://doi.org/10.23971/altarib.v8i1.1986

Davis, J. M. (2013). Supporting creativity, inclusion and collaborative multi-professional learning. Improving Schools, 16(1), 5-20. https://doi.org/10.1177/1365480213480260

Donald, R. C., Jenkins, D. B., \& Metcalf, K. K. (2006). The act of teaching. New York: McGraw Hill.

Haniah, H. (2014). Pemanfaatan teknologi informasi dalam mengatasi masalah belajar bahasa Arab. Al-Ta'rib: Jurnal Ilmiah Program Studi Pendidikan Bahasa Arab IAIN Palangka Raya, 2(1). https://doi.org/10.23971/altarib.v2i1.588

Ilmiani, A. M., Ahmadi, A., Rahman, N. F., \& Rahmah, Y. (2020). Multimedia interaktif untuk mengatasi problematika pembelajaran bahasa Arab. Al-Ta'rib: Jurnal Ilmiah Program Studi Pendidikan Bahasa Arab IAIN Palangka Raya, 8(1), 17-32. https://doi.org/10.23971/altarib.v8i1.1902

Julaeha, S. (2011). Virtual learning: Pemanfaatan teknologi informasi dan komunikasi untuk meningkatkan kualitas pembelajaran. Majalah Ilmiah Pembelajaran, 6(2), 1-9.

Khomsah, A. F., \& Imron, M. (2020). Pembelajaran bahasa Arab melalui kolaborasi metode questioning dan media kahoot. Tarbiyatuna: Jurnal Pendidikan Ilmiah, 5(1), 99-118.

Linur, R., \& Mubarak, M. R. (2020). Facebook sebagai alternatif media pengembangan mahara kitābah. Jurnal Naskhi: Jurnal Kajian Pendidikan Dan Bahasa Arab, 2(1), 8-18. https://doi.org/10.47435/naskhi.v2i1.154 
ALSUNIYAT: Jurnal Penelitian Bahasa, Sastra, dan Budaya Arab

Makrufah, Y. K. (2019). Kitābah sebagai media komunikasi tulisan. Seminar Nasional Bahasa Arab Mahasiswa III Tahun 2019 HMJ Jurusan Sastra Arab Fakultas Sastra Universitas Negeri Malang.

Media, K. C. (t.t.). Guru, ini panduan mengajar jarak jauh dari sekolah lawan corona halaman all. Retrieved April 30, 2020, from KOMPAS.com website: https://edukasi.kompas.com/read/2020/03/23/175105071/guru-ini-panduan mengajar-jarak-jauh-dari-sekolah-lawan-corona

Mubarak, M. R., Wahdah, N., Ilmiani, A. M., \& Hamidah, H. (2020). Penggunaan vlog dalam pembelajaran mahārah kalam. Al Mi'yar: Jurnal Ilmiah Pembelajaran Bahasa Arab dan Kebahasaaraban, 3(1), 109-126. https://doi.org/10.35931/am.v3i1.209

Mustofa, S. (2011). Strategi pembelajaran bahasa Arab inovatif. Malang: UIN-Maliki Press.

Nugrawiyati, J. (2017). Cooperative Learning dalam Pembelajaran Bahasa Arab Berbasis Kurikulum 2013. Al-Murabbi: Jurnal Studi Kependidikan dan Keislaman, 3(2), 142-158.

Rosyidah, A., \& Basid, A. (2017). Analisis diagnostik kesulitan belajar mahārah al-kitābah mahapeserta didik jurusan bahasa dan sastra Arab angkatan 2015 UIN Maulana Malik Ibrahim Malang. In Prosiding Seminar Nasional Bahasa Arab Mahapeserta didik I Tahun 2017. Malang: UM Press.

Sa`diyah, H. (2019). Mahârah al-kitâbah bagi mahapeserta didik melalui update status pada media whatsapp. AL-AF'IDAH: Jurnal Pendidikan Bahasa Arab Dan Pengajarannya, 3(2), 23-37.

Srinivas, H. (2011). What is collaborative learning. The Global Development Research Center, 2(12), 491-495.

Trilling, B., \& Fadel, C. (2009). 21st Century Skills: Learning for Life in Our Times. John Wiley \& Sons.

Video Conferencing, Web Conferencing, Webinars, Screen Sharing. (t.t.). Retrieved March 19, 2020, from Zoom Video website: https://zoom.us/

Warsono, M. S. (2013). Pembelajaran aktif. Bandung: PT Remaja Rosdakarya.

World Health Organization. (t.t.). Retrieved May 1, 2020, from https://www.who.int. 